\title{
Business Models Innovation and Venture Capital Intention of Technology Entrepreneurship Projects: Inverted U-moderating Role of Technological Innovation
}

\author{
Shushan Zhang ${ }^{1, a}$, Beibei Gao ${ }^{2, b,{ }^{*}}$ and Lei Sun ${ }^{3, c}$ \\ ${ }^{1}$ School of Business, Northeast Normal University, Changchun, Jilin Province, China \\ 2 School of Business, Northeast Normal University, Changchun, Jilin Province, China \\ ${ }^{3}$ School of Business, Northeast Normal University, Changchun, Jilin Province, China \\ aZhangss591@nenu.edu.cn, bBei_beigao@163.com, cLeisun_nenu@163.com \\ ${ }^{*}$ Corresponding author
}

Keywords: Technological entrepreneurship projects, Business model innovation; Technological innovation, Venture capital intention

\begin{abstract}
This paper obtains relevant data set of 199 technology entrepreneurship projects from China domestic entrepreneurial reality show, and empirically analyzes the impact of business model innovation on venture capital intention and the moderating role that technological innovation plays between them in the process of technology entrepreneurship projects financing. The study found that: technological innovation plays an inverted Umoderating role in the relationship between business model innovation and venture capital intention.
\end{abstract}

\section{Introduction}

Venture capital has become an important financing channel in the development process of start-up companies. The intention of venture capital will be affected by many factors. Many scholars have conducted in-depth analysis of the investment decision-making process and its influencing factors $[1,2]$. In order to win the favor of investors, start-ups must make innovation in these areas.

Most of the traditional innovations are technological innovations. Many companies have achieved commercial success through innovative business models. A large number of existing studies have shown that business model innovation has a significant positive effect on corporate performance. The business model can well describe the value of technology entrepreneurship and is an effective way to realize it. The innovation of the business model can increase the attractiveness of technology entrepreneurship projects to venture capital. Studies have shown that technological innovation and business model innovation are closely linked. For technology entrepreneurship projects, technology has always been crucial, and the degree of technological innovation may affect the role of business model innovation.

Therefore, this paper taking the technological innovation as moderating variable, proposes a theoretical model about the relationship between business model innovation and venture capital intention of technology entrepreneurial projects, and uses the China domestic entrepreneurial reality show to obtain relevant data set and carry out an empirical analysis.

\section{Literature review and hypotheses}

\subsection{Business model innovation and venture capital intention}

With the popularization of the information technology, the strong vitality and competitiveness of business model innovation has attracted increasing attention of scholars. On the one hand, a good business model is a necessary condition to realize potential technological value, and it can help companies to successfully carry out the commercialization of technology [3]. On the 
other hand, technological entrepreneurship is technology and knowledge-intensive. Hence it's often difficult to understand for stakeholders such as investors and customers. Business model can give a comprehensive explanation for this complex process and expound its value to make technology entrepreneurship easier to understand, increasing the legitimacy and reliability of innovation, and reducing uncertainty $[4,5]$. Business model innovation is conducive for start-up companies to demonstrate their legal status and obtain the recognition of stakeholders [6]. Xu and Dan proposed a venture capital decision model which includes three dimensions: the quality and ability of entrepreneurs [7], the business model of project, and the conditions of start-up companies. Therefore, we hypothesize:

H1: Business model innovation has a positive effect on venture capital intention in technology entrepreneurship projects

\subsection{The moderating role of technological innovation}

Most of the existing studies have shown that the strengthening of technological innovation should be linear, which means the higher the degree of technological innovation, the stronger the impact of business model innovation on venture capital intention. However, the dependent variables of previous studies are mostly corporate performance and that of this study is the investment intention of venture capital. The willingness of investors to participate in the startups' management will also affect their investment intention. After investing in start-up companies, venture capital can participate in its subsequent strategic and operational activities and be the designer of business model [8]. When the level of technological innovation is high, investors will focus more on technology and have higher willingness to participate in management. They are willing to use their relevant resources and experience to build a rational and efficient business model for startups, which can make up for the lack of startups' business model. Therefore, this study believes that technological innovation has a non-linear role in regulating the relationship of business model innovation and venture capital intention. Within a certain range, the moderating role of technological innovation increases as the increase of innovation degree. When technological innovation reaches a higher point, the importance of business model innovation is relatively reduced and its impact on venture capital intention is weaken, that is, as the degree of technological innovation increases, the positive impact of business model innovation on venture capital intention increases first and then weakens. Therefore, we hypothesize:

$\mathrm{H} 2$ : Technological innovation has an inverted U-shaped moderating role between business model innovation and venture capital intention.

\section{Study design}

\subsection{Data collection and measures}

The empirical data set of this research comes from the entrepreneurial reality show- "The Entrepreneurship Elites" broadcast by CCTV. We selects 108 programs from January 2016 to March 2018, a total of 321 entrepreneurial projects. Finally, 199 projects were obtained.

In this study, technological innovation and business model innovation are measured by 5-point Likert scale. After the full argument and analysis of the research team, three team members respectively scored each variable of each entrepreneurial project according to the video and related data. The measurement of technological innovation mainly refers to the research of Yang and Hou $[9,10]$ on technical evaluation and technical innovation. The measurement of business model innovation adopted the scales employed by Zottc and Amit, Pang et al, and Guo et al $[11,12,13]$. This study uses the investors' investment intention on entrepreneurial projects to measure the venture capital intention. 


\subsection{Reliability and validity}

The reliability and validity of the measurement tools are evaluated. The Cronbach's $\alpha$ coefficients of business model innovation and technical innovation are 0.904 and 0.894 , indicating that the two scales both have good reliability. The factor load of business model innovation is in a range of 0.75-0.93 $(\chi 2 / \mathrm{df}=0.785 ; \mathrm{RMSEA}=0.000 ; \mathrm{CFI}=1.000 ; \mathrm{NFI}=0.997)$ and that of technological innovation is in a range of 0.76-0.91 $(\chi 2 / \mathrm{df}=2.141$; RMSEA=0.076; $\mathrm{CFI}=0.995 ; \mathrm{NFI}=0.991$ ). All fit indicators reached acceptable levels. And the AVE values of all scales were greater than 0.5 (business model innovation 0.715 ; technological innovation 0.692), indicating that the scales have good convergence validity.

\section{Regression analysis results}

Each hypothesis was verified by constructing a regression model. The results are shown in Table 1. In Table 1, the dependent variable is venture capital intention. Model 1 only adds the control variables. Model 2 adds the business model innovation on the basis of the control variables, and model 3 adds the technological innovation and the first-order interaction of technology innovation and business model innovation on the basis of model 2. Model 4 adds the second-order interaction of technological innovation and business model innovation on the basis of Model 3. The variance inflation factors (VIF) in all models are less than 10, so there is no serious multicollinearity problem among the independent variables.

Test the inverted U-moderating role of technological innovation. From model 4, we can see that after adding the second-order interaction of technological innovation and business model innovation, the model's $\mathrm{R} 2$ has increased to 0.447 , and the overall explanatory ability has been improved. The impact of business model innovation on venture capital intention remains significant $(\beta=0.085, \mathrm{P}<0.001)$. The first-order interaction is positive significant $(\beta=0.276, \mathrm{P}<0.01)$, and the second-order interaction is negative significant $(\beta=-0.276, \mathrm{P}<0.01)$, indicating technological innovation has an inverted U-shaped moderating role between business model innovation and venture capital intention. See Fig.1 for details. The positive impact of business model innovation on venture capital intention increases first and then weakens as technology innovation increases. Therefore, $\mathrm{H} 2$ is supported.

Table 1 Regression analysis results

\begin{tabular}{|c|c|c|c|c|c|}
\hline & \multicolumn{4}{|c|}{ Venture capital intention } \\
\hline & & Model 1 & Model 2 & Model 3 & Model 4 \\
\hline \multirow{5}{*}{$\begin{array}{c}\text { Control } \\
\text { variables }\end{array}$} & $\begin{array}{l}\text { Entrepreneur's } \\
\text { gender }\end{array}$ & -0.076 & -0.045 & $-0.072 *$ & $-0.073^{*}$ \\
\hline & Entrepreneur's age & -0.015 & 0.001 & -0.010 & -0.009 \\
\hline & $\begin{array}{l}\text { Entrepreneur's } \\
\text { education }\end{array}$ & $0.035 * * *$ & $0.030 * * *$ & 0.006 & 0.007 \\
\hline & $\begin{array}{l}\text { Entrepreneur's } \\
\text { experience }\end{array}$ & 0.011 & -0.001 & -0.005 & -0.004 \\
\hline & Project valuation & 0.019 & $0.029 *$ & 0.010 & 0.009 \\
\hline $\begin{array}{c}\text { Independent } \\
\text { variable }\end{array}$ & $\begin{array}{l}\text { Business model } \\
\text { innovation(BMI) }\end{array}$ & & $0.156^{* * *}$ & $0.082 * * *$ & $0.085 * * *$ \\
\hline Moderator & $\begin{array}{l}\text { Technological } \\
\text { innovation(TI) }\end{array}$ & & & $0.087 * * *$ & $0.096 * * *$ \\
\hline $\begin{array}{l}\text { First-order } \\
\text { interaction }\end{array}$ & $\mathrm{TI} * \mathrm{BMI}$ & & & 0.006 & $0.276^{* *}$ \\
\hline $\begin{array}{l}\text { Second-order } \\
\text { interaction }\end{array}$ & $\mathrm{TI}^{\wedge} 2 * \mathrm{BMI}$ & & & & $-0.276^{* *}$ \\
\hline \multicolumn{2}{|r|}{$\mathrm{R}^{2}$} & 0.109 & 0.301 & 0.423 & 0.447 \\
\hline \multicolumn{2}{|c|}{ Adjust $\mathrm{R}^{2}$} & 0.086 & 0.279 & 0.398 & 0.421 \\
\hline \multicolumn{2}{|r|}{$\mathrm{F}$} & $4.734 * * *$ & $13.796 * * *$ & $17.395 * * *$ & $16.966^{* * * *}$ \\
\hline
\end{tabular}

Note: $* \mathrm{P}<0.05 ; * * \mathrm{P}<0.01 ; * * * \mathrm{P}<0.001$. 


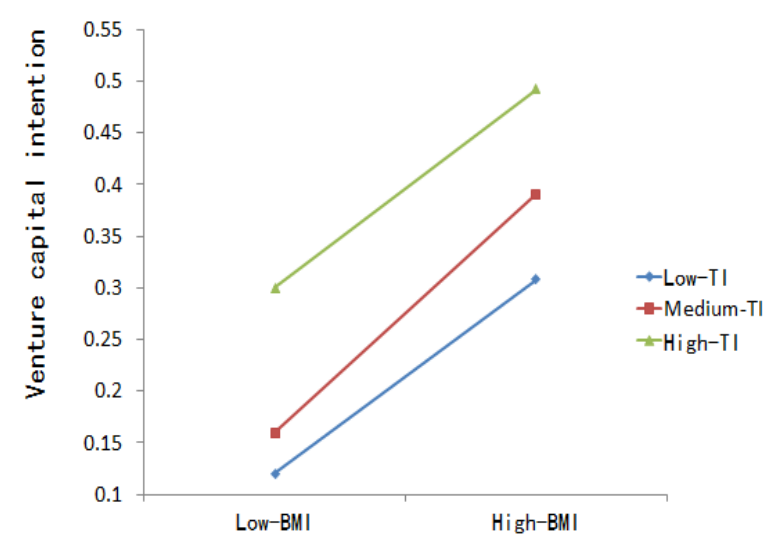

Fig. 1 The moderating role of technological innovation

\section{Discussion and conclusions}

This paper constructs a theoretical model that business model innovation influences the venture capital intention, taking technological innovation as a moderating variable, and conducts an empirical test on the data of technology entrepreneurship projects collected through the entrepreneurial reality show. The research content has important theoretical significance and practical value.

There are two limitations of this study are as follows: The projects data are not fully displayed; The independent variable and moderating variable are measured in a certain personal preferences. In future research, we can track the entrepreneurial projects and carry out other related researches in depth on the basis of this study.

\section{Acknowledgement}

This research was financially supported by the National Social Science Foundation of China (Grant NO. 18BJY180).

\section{References}

[1] T. T. Tyebjee, A. V. Bruno, A model of Venture Capitalist Investment Activity, Management Science, Vol. 9, pp. 1051-1066, 1984.

[2] J. Su, High-Tech Enterprise Risk Investment Evaluation Study, Science \& Technology Progress and Policy, Vol. 30, pp. 124-127, 2013.

[3] M. Cucculelli, C. Bettinelli, Business models, intangibles and firm performance: evidence on corporate entrepreneurship from Italian manufacturing SMEs, Small Business Economics, Vol. 45, pp. 329-350, 2015.

[4] L. Doganova, R. M. Eyquem, What do business models do? Innovation devices in technology entrepreneurship, Research Policy, Vol. 38, pp. 1559-1570, 2009.

[5] M. Lounsbury, M. A. Glynn, Cultural entrepreneurship: stories, legitimacy and the acquisition of resources, Strategic Management Journal, Vol. 22, pp. 45-56, 2001.

[6] Y. Z. Du, Y. L. Zhang, and B. Ren, Showing or Hiding Competitive Advantage: The U-shaped Relationship of New Firm Competitor Orientation and Performance and the Mediating Role of Organization Legitimacy. Management World, Vol. 7, pp. 96-107, 2012.

[7] X. S. Xu, Z. Y. Dan, Fuzzy Comprehensive Evaluation Model for Investment Risk of High-tech Projects, Quantitative \& Technical Economics, Vol. 1, pp. 23-25, 2000. 
[8] Y. N. Gou, J. Dong, Influence of venture capital background on firms' technological innovation, Science Research Management, Vol. 35, pp. 35-42, 2014.

[9] Q. Yang, Y. Li, and L. S. Yin, Compositive Assessment Model of Venture Enterprises' Investment Value Based on Grey Theory, Journal of Wuhan University of Technology, Vol. 4, pp. 495-498, 2005.

[10] T. Hou, D. H. Zhu, SWOT analysis based innovation project technology assessment and decision research, Science Research Management, Vol. 4, pp. 1-6, 2006.

[11] C. Zottc, R. H. Amit, Designing Your Future Business Model : an Activity System Perspective, Long Range Planning, Vol. 43, pp. 216-226, 2010.

[12] C. W. Pang, Y. Li, and G. Duan, Integrative Capability and Firm Performance: The Mediating Effect of Business Model Innovation, Journal of Management Science, Vol. 28, pp. 31-41, 2015.

[13] T. Guo, Y. Wu, and H. D. Liu, The Study of the effect of entrepreneurs' background characteristics on the performance of technology startups: The mediating role of business model innovation, Science and Technology Progress and Policy, Vol. 34, pp. 86- 91, 2017. 